UDC 378.147:81'243

DOI: https://doi.org/10.31470/2415-3729-2020-11-9-26

\title{
Methodological and Didactic Fundamentals of Foreign Language Communicative Competence Formation in Distance Learning
}

\section{Valentyna Bebykh}

Doctor of Philosophy in Pedagogy (Ph.D),

Associate Professor of the Department of Foreign Languages,

Bukovyna State Medical University,

$\triangle 2$, Teatralna Square, Chernivtsi, Ukraine, 58002

E-mail: vabek@i.ua

ORCID: 0000-0003-4378-0978

\section{Raisa Kotelevska}

Lecturer of the highest category,

College of Yuriy Fedkovich Chernivtsi National University, Ukraine, Chernivtsi

$\triangle 20$, Shterna Str., Chernivtsi, Ukraine, 58002

E-mail: raisakotilevska@gmail.com

ORCID: 0000-0003-2473-9283

Date of receipt of the article: April 15, 2020 Article accepted for publication: June 01, 2020

\section{Методологічні та дидактичні засади формування іншомовної комунікативної компетентності в умовах дистанційного на- вчання}

\section{Валентина Володимирівна Бебих}

кандидат педагогічних наук, доцент кафедри іноземних мов, Буковинський державний медичний університет $\triangle$ Театральна площа, 2, м. Чернівці, Україна, 58002 


\section{Раїса Аурелівна Котелевська}

викладач вищої категорії

коледж Чернівецького національного університету

ім.Ю.Федьковича

$\triangle$ вул. Штерна, 1, м.Чернівці, Україна, 58002

Дата надходження статті: 15 квітня 2020 p.

Стаття прийнята до друку: 01 червня 2020 р.

\section{Abstract}

The study deals with the theoretical justification of pedagogical conditions and methodical principles of the future specialists' foreign language communicative competence formation in the conditions of distance learning. The result of the theoretical part of the study was specifying a complex application of computer and multimedia technologies as the system of pedagogical conditions for foreign language distance learning.

Methods of analysis, synthesis, generalization and modeling were used to develop a pedagogical model of remote formation of speech skills and abilities of students. The structural method and system analysis were used to display the relationships between the basic components of the model.

The constructed model of the foreign language distance learning includes the following structural components: educational technologies, basic principles, requirements for educational and methodological support.

The analysis of the basic concepts and definitions concerning distance learning allowed to define requirements to the training process in the context of our research which on component structure are content-structural and methodical. The basic components of the system of training are outlined as conceptual basis, content part and procedure part. The functions of computer technology, multimedia support, tasks for the teacher and student opportunities are defined. 
Thus, the result of the study is the development of contentstructural model of foreign language communicative competence of the future specialists based on the multimedia content application as an integrated component of complex methodological support and computer technology as a form of process organization. The authors made a conclusion that the effectiveness of using these learning technologies is conditioned by the specific objectives of the subject studying and the practicability of their use for ensuring the implementation of support functions (the main are: determining the degree of the management of student's learning activities by a teacher at all levels; determining the degree of the student's learning activities self-management; indirect management of selfstudy activities for preventing stress; providing a feedback system; ensuring self-control).

Key words: distance learning, computer technologies, multimedia technologies, foreign language communicative competence.

\section{References}

1. Romanova, H. M., Artiushyna M. V. \& Slatvinska O. A. (2015). Pedahohichni tekhnolohii u profesiinii pidhotovtsi kvalifikovanykh robitnykiv [Pedagogical technologies in the professional training of skilled workers]. Kyiv : Instytut profesiino-tekhnichnoi osvity NAPN Ukrainy [in Ukrainian].

2. Vitvytska, S. S. (2006). Osnovy pedahohiky vyshchoi shkoly [Fundamentals of higher school pedagogy]. Kyiv : Tsentr navchalnoi literatury [in Ukrainian].

3. Tarnopolskiy, O. B. \& Kozhushko, S. P. (2004). Metodika obucheniya angliyskomu yaziku dlya delovogo obscheniya [Methods of teaching English for business communication]. Kiev : Lenvit [in Russian].

4. Serdiukov, P. I. (2001). Tekhnolohiia rozrobky kompiuternykh prohram z inozemnykh mov [Technology for computer programs development in foreign languages]. Kiev : Lenvit [[in Ukrainian].

5. Zimnyaya, I. A. (2004). Pedadogicheskaya psihologiya [Pedagogical psychology]. Moskva : Logos [in Russian]. 
6. Savonko, E. I. (1980) Samootsenka i motivatsiya kak faktoryi sotsialno-psihologicheskoy adaptatsii studentov $\mathrm{k}$ usloviyam v vuze. [Self-assessment and motivation as factors of socio-psychological adaptation of students to conditions at a university]. Psihologiya uchebnoy deyatelnosti studentov pri ovladenii inostrannyimi yazyikami v yazyikovom vuze : Sbornik nauchnyih trudov. Moscow : Mosk. gos. ped. univ. inostr. jazykov M. Toreza, 162, 162-175 [in Russian].

7. Lapidus, B. A. (1986). Problemyi soderzhaniya obucheniyu yaziku v yazyikovom vuze [Content problems of language teaching at languages university]. Moscow : Vyssh. shk. [in Russian].

8. Bihych, O. B. (2005). Osvitnia avtonomiia studenta v protsesi metodychnoi osvity [Educational autonomy of the student in the process of methodical education]. Visnyk KNLU - Bulletin of Visnyk of Kyiv National Linguistic University, 8, 257 [in Ukrainian].

9. Riabokon, O. V. (2004). Kontseptsiia metodychnoho zabezpechennia pisliadyplomnoi inshomovnoi samopidhotovky menedzheriv iz zovnishnoekonomichnykh zviazkiv [The concept of methodological support for postgraduate foreign language self-training of managers in foreign economic relations]. Inozemni movy - Foreign Languages, 1, 31 [in Ukrainian].

10. Kukharenko, V. M. (2012). Pro systemu dystantsiinoho navchannia $\mathrm{u}$ vidkrytomu dystantsiinomu kursi [About the system of distance learning in an open distance course]. Informatsiini tekhnolohii v osviti - Information Technologies in Education, 11, 32-42 [in Ukrainian].

11. Stefanenko P. V. (2002). Distancionnoe obuchenie v vysshej shkole [Distance learning in higher education]. Doneck : DONNTU [in Russian].

12. Polat, E. S., Moiseeva, M. V. \& Petrov, A.E. (2005). Distancionnoe obuchenie [Distance learning]. Moscow : Vlados [in Russian].

\section{Вступ}

Дистанційне навчання (ДН), яке у час карантину вкоренилося в передачі знань і формуванні умінь і навичок студентів, 
може стати трендом вищої освіти у наступні роки. У зв’язку 3 поширенням коронавируса освітні заклади України впроваджували ДН переважно в експериментальному режимі. У навчальний процес залучалися: інтернет-платформи Zoom, Google Meet, Google Classcroom, MyEnglishLab, телеграм канал тощо. Активне впровадження в навчальний процес ДН, викликане сьогоденням, обумовлює подальше дослідження змісту і методів навчання. Незначний за обсягом час існування системи дистанційної освіти був недостатнім для створення розвинених наукових теорій у цій галузі. Зарубіжні та вітчизняні напрацювання стосуються переважно технічної та організаційної сторін функціонування даної системи. Аналіз і узагальнення досвіду дистанційної освіти, який проводили О.О. Андреєв, В.Ю. Биков, И.М. Ібрагимов, В.М. Кухаренко, В.І. Овсянников, С.С. Полат, Н.Г. Сиротенко, В.І. Солдаткін, Н.В. Сороко, П.В. Стефаненко дали змогу виокремити низку властивостей, що розкривають ii сутність. Особливе місце у формуванні системи ДН займають роботи, в яких аналізується процес індивідуалізації навчання, таких педагогів i психологів, як Ю.К. Бабанський, М.А. Данілов, Д.В. Ельконін, М.И. Махмутов, О.М. Пехота, I.Т. Огородников, П.І. Сікорский. Найбільшу значимість досліджень теоретико-методологічних основ організації ДН та особливостей його дидактичного і методичного забезпечення представляють роботи Є.К. Балафанова, М.А. Вінницької, .Г. Гаєвської, В.П. Демкина, Є.І. Дмитрієвої, М.В. Моісеєвої, Е.С. Полат, А.М. Татенова, В.П. Тихомирова.

Метою статті $є$ окреслення педагогічних умов та методичних принципів формування іншомовної комунікативної компетентності майбутнього фахівця на основі розробленої педагогічної моделі навчання іноземних мов

Актуальність статті зумовлена перспективністю впровадження ДН, з одного боку, та недостатнім рівнем теоретичного обгрунтування методологічних та дидактичних вимог щодо дистанційного формування іншомовної комунікативної компетентності студентів. 


\section{Матеріал і методи досліджень}

3 посиланням на науково-методичну літературу, в якій існує понад трьохсот визначень поняття «технологія навчання», ми розглядаємо цю системну категорію як послідовність дій викладача і студентів для гарантованого досягнення навчальних цілей при вивченні навчального предмета, що передбачає застосування певної сукупності методів і засобів навчання, реалізацію змісту навчання (Романова, Артюшина, Слатвінська, 2015). В основу наших досліджень ми покладаємо концептуальні положення організації навчального процесу у вищій школі, виведених С.С.Вітвицькою, зокрема щодо застосування ДН як технології, яка базується на принципах відкритого навчання, широко використовує комп'ютерні навчальні програми різного призначення та створює за допомогою сучасних телекомунікацій інформаційне освітнє середовище для доставки навчального матеріалу та спілкування.

Методи дослідження на науково-теоретичному рівні включали в себе: метод формального аналізу - аналіз вітчизняної та зарубіжної літератури методики викладання іноземних мов (IM), психології, педагогіки та психолінгвістики за темою дослідження; методи синтезу, формалізації, узагальнення $і$ моделювання лягли в основу розробки моделі організації дистанційного формування мовленнєвих навичок і вмінь студентів. Структурний метод та системний аналіз застосовувалися для відображення базових компонентів моделі та зв'язків між її окремими елементами.

Ми розглядаємо ДН як сукупність технологій, що забезпечують доставку студентам основного обсягу навчального матеріалу, інтерактивну взаємодію студентів і викладачів у процесі навчання, надання студентам можливості самостійної роботи з навчальними матеріалами. Говорячи про сукупність технологій, у нашому дослідженні ми маємо на увазі поєднання комп'ютерної технології як основи функціонування ДН та мультимедійних технологій як інструменту інтегрування мультимедійного контенту у навчальний процес. Тобто, в основу розробки методичної концепції покладено інтегрування комп'ютерної та мультимедійних технологій у про- 
цес формування іншомовної комунікативної компетентності майбутнього фахівця.

Попередній аналіз основних понять та визначень стосовно організації ДН дозволяє нам визначитись 3 пріоритетами щодо педагогічних умов, що впливають на якість знань студентів та на ефективність навчального процесу. Під поняттям «педагогічні умови» в наукових працях дослідників розуміють чинники або фактори, які зумовлюють і визначають сутність певної навчальної технології, забезпечують активність студентів i стимулюють свідоме засвоєння навчального матеріалу. Визначення педагогічних умов проводиться з врахуванням характернимих рис дистанційної освіти, які включають в себе: гнучкість, модульність; економічну ефективність; координаторську роль викладача; спеціалізований контроль якості освіти; використання спеціалізованих технологій і засобів навчання (Вітвицька, 2006: 170-175).

Підготовка до організації навчального процесу починається i3 глибокого аналізу: цілей навчання, дидактичних можливостей нових технологій передачі навчальної інформації, вимог до технологій ДН конкретних дисциплін та психологічних аспектів, які повинен враховувати викладач. Активна самостійна діяльність, яка $є$ базовою складовою ДН, визначає організацію навчального процесу із застосуванням комп'ютерної технології як однієї 3 найбільш важливих умов його функціонування. Ми розглядаємо комп’ютеризовану форму як «спрямовану, внутрішньо мотивовану, структуровану самим суб'єктом (студентом) сукупність виконуючих дій та діяльність, яка коригується ним в процесі та за результатом» 3 використанням навчальних матеріалів на основі опосередкованого управління 3 боку викладача (Тарнопольський \& Кожушко, 2004).

Нові суспільні вимоги щодо володіння іноземною мовою (IM) сприяли виведенню специфічних методичних принципів інтерактивності, інтеграції, мовленнєво-мисленнєвої активності, контекстуалізації, домінуючої ролі безперекладної семантизації, які лежать в основі як навчання IM взагалі, так і формування 
соціокультурної компетенції з IM. Проблема інтеграції навчальних комп’ютерних засобів у навчання викликала необхідність уточнення окремих принципів у сучасній їх реалізації у процесі навчання IM. Дидактичні принципи, на яких грунтується комп’ютерне навчання IM були виведені П.І. Сердюковим. До них він відніс: активність, проблемність, свідомість, наочність, індивідуалізацію, системність, функціональність, інтегрованість, комунікативність, лінгвістичну адекватність, реактивність, адаптивність, мінімізацію негативних впливів (Сердюков, 2001).

Застосування ДН іноземної мови диктує свої педагогічні умови та принципи організації навчального процесу. Ретельно проаналізувавши загальнометодичні принципи викладання IM, a також принципи, на яких базується комп'ютерне навчання IM, ми поставили перед собою завдання узгодити їх і побудувати систему принципів, які лежать в основі ДН іноземної мови.

\section{Результати та їх обговорення}

Вивчення науково-методичної літератури та досвід роботи вказує на важливість забезпечення високої внутрішньої мотивації самостійної навчальної діяльності студента. Оскільки активна самостійна діяльність студентів є базовою складовою ДН, мотивацію ми відносимо до основних принципів, на якому грунтується організація ДН іноземної мови. Зацікавленість, інтерес, що входять до мотиваційної сфери, значною мірою впливають на якість засвоєння іншомовного матеріалу. А саму мотивацію психологи називають «запускним механізмом» будьякої людської діяльності, зокрема, самостійної роботи студента. Процесуальна мотивація являє собою так зване змістовне «енергетичне» ядро структури, від якого залежить стійкість та особливості iii змін (Зимняя, 2004). Однак, при цьому слід брати до уваги й інші види мотивації, серед яких С.I. Савонько виділяє, крім орієнтації на процес, орієнтацію на результат, на оцінку викладача, на уникнення неприємностей (Савонько, 1980).

Вважаючи принцип індивідуалізащіï одним із основних принципів організації самостійної роботи студентів (СРС), ми 
розглянули його в двох площинах і прийшли до висновку, що принцип лінгвістичної адекватності навчального матеріалу слід розглядати як основний у лінгвістичній площині, оскільки він характеризується методичною доцільністю, тобто відповідністю цілям і завданням мовної компетенції (Рис. 1.1). Цей принцип відповідає стадії відбору навчального забезпечення. Як правило, застосувуються або програмні продукти, що створюються безпосередньо викладачами, або використовуються ресурси мережі Інтернет. Ефективність навчання будь-якого виду мовленнєвої діяльності значною мірою залежить від вирішення проблеми відбору навчального матеріалу. У методичній літературі ця проблема вирішується по-різному залежно від характеру матеріалу та конкретних цілей роботи 3 ними. Виходячи 3 цього, дослідники розробили вимоги до навчальних матеріалів та принципи і критерії їх відбору. Слідом за Б.А. Лапідусом ми розглядаємо принцип відбору навчального матеріалу як основне положення, що визначає критерії відбору, а критерій служить інструментом відбору, маркером, за яким визначається включення або не включення одиниці відбору в мінімум, за допомогою якого якісно та кількісно оцінюється текстовий матеріал 3 метою його використання чи невикористання відповідно до цілей (Лапидус, 1986). Серед розроблених в методиці критеріїв відбору навчального матеріалу ми взяли до уваги мовні критерї̈, критерї̈ змісту та кількісні критерї i керуючись ними, окреслили ряд критеріїв відбору матеріалу для формування іншомовних умінь та навичок. До них відносимо: автентичний характер, професійно-практичну иінність, ситуативну необхідність, соиіокультурну изінність, цүілісність і повноту відібраного корпусу текстів.

Можливості використання мережі Інтернет як джерела додаткових матеріалів для викладача та студента безмежні. У роботі 3 навчальними сайтами обирається той рівень складності, який відповідає рівню підготовки студентів. Окрім мовного матеріалу враховуються і такі параметри як структура розділів, обсяг вправ, текстів, тестів та прогнозований навчальний час роботи користу- 
вача (Рис. 1.2). Через ці параметри уможливлюється здатність певною мірою керувати навчальною діяльністю. Отже, розглядаючи це у психофізіологічній площині, ми можемо сказати, що опосередковане керування навчальною діяльністю відбувається через зміст та обсяг завдань.

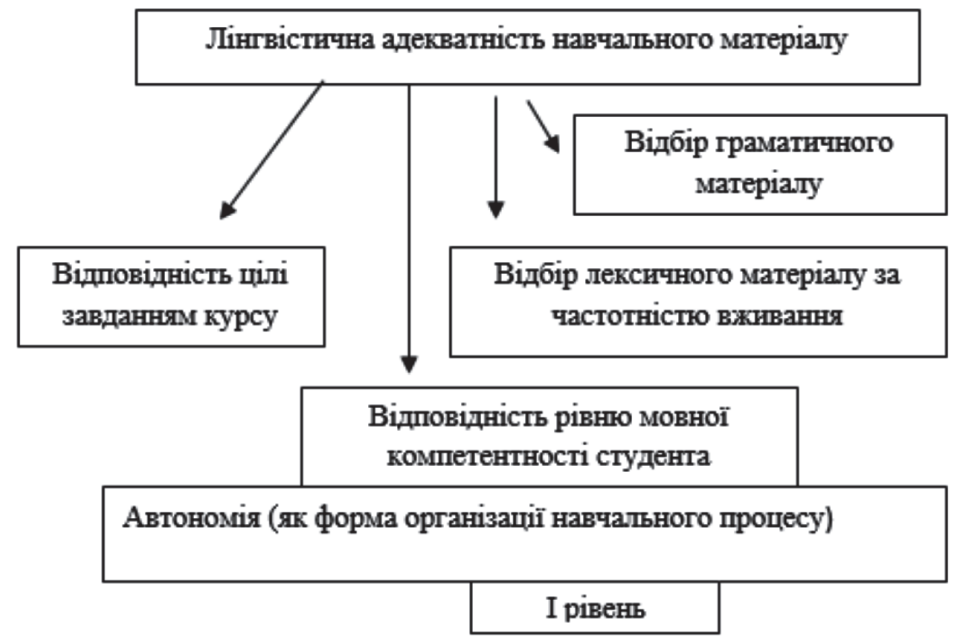

Рис. 1.1. Лінгвістична площина (внутрішня мотивація)

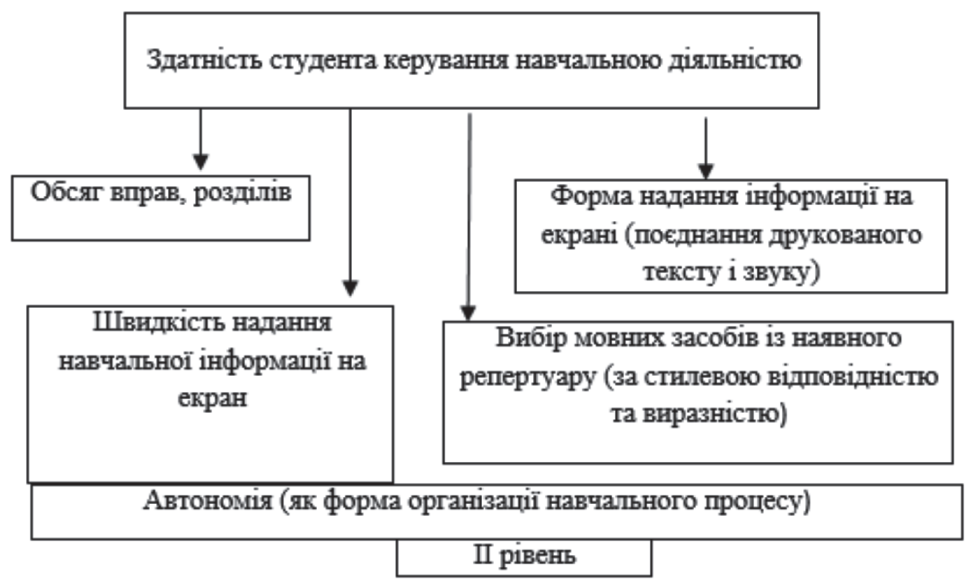

Рис. 1.2. Психофізіологічна площина (процесуальна мотивація) 
До основних принципів навчання іноземним мовам в комп'ютеризованому середовищі відносимо принции комунікативності. Він зумовлює практичну мету навчання й вивчення іноземних мов, а саме: оволодіння іншомовним спілкуванням шляхом формування й розвитку комунікативної компетенції та її складових.

Поняття автономії у вітчизняній методиці навчання IM розглядається в розрізі СРС, післядипломної іншомовної самопідготовки спеціалістів та методичної освіти. О.Б. Бігич (Бігич, 2005). Питання рівнів автономії суб'єктів навчання в межах вивчення ділової англійської мови досліджувалось О.Б. Тарнопольським (Тарнопольський \& Кожушко, 2004). Розглядаючи слідом за О.В. Рябоконь автолінгводидактичне середовище як «сукупність зовнішніх факторів самонавчання іноземних мов, яка інтегрує джерела усної і письмової, навчальної і не навчальної інформації, а також технічні та інші засоби» (Рябоконь, 2004) ми можемо змінювати його і тим самим змінювати засоби впливу на суб'єкта самонавчання, при цьому зменшуючи чи збільшуючи рівень автономії суб'єкта навчання. В комп'ютеризованому середовищі це реалізується через наступні функції комп'ютерних матеріалів: концептуальну (визначення цілей і завдань, формулювання принципів їх реалізації); селективну (відбір навчального матеріалу); конструктивно-трансформаційну (структура мультимедійних матеріалів).

Виводячи мотивацію, індивідуалізацію, комунікативність та автономію в основні принципи організації дистанційного навчання у процесі навчення IM, слід зазначити, що разом із підпорядкованими їм принципами - предметність, проблемність, лінгвістична адекватність, адаптивність, наочність, свідомість, активність, зворотний зв'язок, інтегрованість, функціональність - вони утворюють систему принципів, які узгоджуються із загальнометодичними принципами, є взаємопов'язаними і взаємозалежними. 
Пошук способів оптимального застосування ДН дозволив нам зробити припущення, що найбільш впливовими факторами на ефективність дистанційної навчальної діяльності $\epsilon$, перш за все, ступінь управління навчальним процесом. Результативність різних форм набуття знань залежатиме від ступеня керованості системи навчання, тобто детермінація ступеня управління на всіх рівнях навчальної діяльності є першочерговою умовою ефективності навчання. Вивчення цього питання дослідниками дає підстави зробити висновок про те, що ДН дає можливість збільшити ступінь свободи студента, зробити систему навчання більш демократичною, змінити модель педагогічної взаємодії, в якій студент із об'єкта навчання перетворюється в суб'єкт навчання, який визначає режим керування своєю навчальною діяльністю. Як зазначають В.М. Кухаренко (Кухаренко, 2012), П.В. Стефаненко (Стефаненко, 2002), С.С. Полат (Полат, 2005) застосування нових організаційних форм навчання принципово змінює спосіб одержання і засвоєння знань, а також взаємодію між студентом та викладачем. Джерелом інформації в цих моделях є бази даних в освітньому просторі в якості доступного навчального мультимедійного контенту. Іншим стає статус викладача, який змінює свої функції і виступає в ролі інструктора навчання, координатора і консультанта, а інтерпретатором знань є студент.

Говорячи про інтеграцію мультимедійних технологій у процес навчання іноземних мов, ми маємо на увазі формування іншомовних комунікативних умінь через мультимедійний контент. Однак відбір мультимедійних матеріалів залишається в компетенції викладача. Виходячи з цього, нашим подальшим завданням є визначення функцій викладача, студента, та дидактичних функцій мультимедійного забезпечення. Перш за все, нам слід визначити, які навчальні функції доцільно передати мультимедійному забезпеченню, так як це являється тільки засобом, а не суб'єктом навчання. 
Аналіз досліджень використання мультимедійних технологій як засобу забезпечення навчального матеріалу та комп’ютерної технології як основи процесу ДН дозволив нам визначити: завдання для викладача, функції мультимедійного забезпечення та можливості студента відповідно до етапів навчального процесу (Табл. 1). Окреслення функцій викладача та дидактичних функцій мультимедійного забезпечення відповідно до фаз навчального процесу дозволяють зробити припущення, що за умови дотримання всіх вимог до використання комп'ютерних засобів та мультимедійних навчальних матеріалів розроблена модель формування мовленнєвих навичок і вмінь забезпечить умови створення оптимального навчального середовища, основою якого є: мотивачія; забезпечення зворотного зв 'язку; індивідуалізація навчання. Визначення мети та завдань, аналіз особливостей ДН в комп'ютеризованому середовищі дають підстави для формування навчальної компетенції студента як основи діяльності головного учасника моделі педагогічної взаємодії «суб’єкт»- «суб’єкт».

Для ефективної педагогічної взаємодії учасників моделі організації ДН суттєво важливим $є$ такий вагомий фактор діяльності самого студента як самококонтроль. У розробці моделі навчання ми брали до уваги два види самоконтролю: 1) самоконтроль як психолінгвістичне явище (внутрішній самоконтроль), який можна визначити як розумові операції щодо відстеження правильності застосування мовленнєвих одиниць у власному мовленні; 2) зовнішній або формальний самоконтроль як дидактичне поняття, який забезпечується спеціально сформованими навчальними вміннями студентів за допомогою ключів у процесі корекції самооцінки мовленнєвих дій.

Обгрунтування дидактичних та загально-методичних принципів, закладених у ДН дозволило нам окреслити вимоги до створення моделі формування іншомовної комунікативної компетентності майбутнього фахівця. За компонентним складом вони є змістово-структурні та методичні. 
Змістово-структурний компонент: оптимальна можливість інтегрування в навчальний процес; відповідність цілям і завданням дисципліни; наявність інструкції щодо роботи 3 мультимедійним контентом; врахування кількості, обсягу, типів і видів вправ та змісту текстового матеріалу; включення відібраних формул спілкування у відповідності до комунікативного завдання; раціональне структурування на окремі розділи.

Методичний компонент: відповідність рівню іншомомовної комунікативної компетенції студента; відповідність етапів роботи механізму сприйняття та механізму запам'ятовування; наявність мотиваційного забезпечення (оформлення, ігрові елементи, доступність, цікавість тощо); забезпечення зворотного зв'язку; системність та цілісність.

Визначені вимоги забезпечують теоретичне підгрунтя і дають підстави передбачати, що дана модель буде здатна інтенсифікувати та індивідуалізувати процес формування іншомовної комунікативної компетенції студентів.

\section{Висновки}

Узагальнюючи вище викладене, можна стверджувати, що ДН передбачає використання мультимедійного контенту як інтегрованого компонента комплексно-методичного забезпечення вивчення іноземних мов та застосування комп'ютерної технології як основи іiі функціонування. Ефективність використання даних технологій навчання обумовлена конкретними завданнями вивчення дисципліни та доцільністю їх використання для забезпечення реалізації підтримуючих функцій, основними серед яких є:

1. Детермінація ступеня управління навчальною діяльністю студента викладачем на всіх рівнях.

2. Детермінація ступеня управління своєю навчальною діяльністю самим студентом.

3. Опосередковане керівництво самостійною навчальною діяльністю, яке запобігає психологічній напрузі.

4. Забезпечення системи зворотного зв'язку

5. Забезпечення самоконтролю. 
Ці узагальнення дають підстави для подальших досліджень оптимальних умов застосування навчальних мультимедійних матеріалів у процесі ДН. Перспективність даного дослідження ми пов’язуємо 3 подальшими розробками методичного та дидактичного забезпечення ДН іноземних мов майбутніх фахівців.

\section{Література}

1. Романова Г.М., Артюшина М.В., Слатвінська О.А. Педагогічні технології у професійній підготовці кваліфікованих робітників : довідник. Київ : Інститут професійно-технічної освіти НАПН України, 2015. 87 с.

2. Вітвицька С.С. Основи педагогіки вищзої школи : методичний посібник для студентів магістратури. Київ : Центр навчальної літератури, 2006. 316 с.

3. Тарнопольський О.Б., Кожушко С.П. Методика обучения английскому язику для делового общения. Киев : Ленвит, 2004. 190 с.

4. Сердюков П.І. Технологія розробки комп 'ютерних програм 3 іноземних мов. Київ : Ленвіт. 2001. 196 с.

5. Зимняя И.А. Педадогическая психология. Москва : Логос, 2004. C. 252.

6. Савонько Е.И. Самооценка и мотивация как факторы социальнопсихологической адаптации студентов к условиям в вузе. Психология учебной деятельности студентов при овладении иностранными языками в языковом вузе : Сборник научных трудов. Вып. 162 . Москва : Моск. гос. пед. унив. иностр. языков М. Тореза, 1980. С. 162-175.

7. Лапидус Б.А. Проблемы содержания обучению язику в языковом вузе. Москва : Высш. шк., 1986. 144 с.

8. Бігич О.Б. Освітня автономія студента в процесі методичної освіти. Вісник КНЛУ. №8. 2005. С. 257.

9. Рябоконь О.В. Концепція методичного забезпечення післядипломної іншомовної самопідготовки менеджерів із зовнішньоекономічних зв'язків. Іноземні мови. 2004. № 1. С. 31.

10. Кухаренко В.М. Про систему дистанційного навчання у відкритому дистанційному курсі. Інформащійні технології в освіті. Випуск 11, 2012. с. 32-42. 
11. Стефаненко П.В. Дистанционное обучение в высшей иколе : Моногр. Донецк : ДОННТУ, 2002. 397 с.

12. Полат Е.С. Дистаниионное обучение / Е.С. Полат, М.В. Моисеева, А.Е. Петров ; 3-е изд., перераб. и доп. Москва : Владос, 2005. $192 \mathrm{c}$.

Бебих В.В., Котелевська Р. А.

\section{Методологічні та дидактичні засади формування іншомовної комунікативної компетентності в умовах дистанційного на- вчання}

\section{Анотація}

Метою статті $є$ обгрунтування педагогічних умов і методичних принципів формування іншомовної комунікативної компетентності майбутнього фахівця в умовах дистанційного навчання. Результатом дослідження $є$ створення педагогічної моделі формування іншомовної комунікативної компетентності на основі використання мультимедійного контенту як інтегрованого компоненту комплексно-методичного забезпечення та комп'ютерної технології як форми організації процесу.

Методи аналізу, синтезу, узагальнення і моделювання лягли в основу розробки моделі. Структурний метод та системний аналіз застосовувалися для відображення зв'язків між ії базовими компонентами.

Обгрунтовано систему педагогічних умов дистанційного навчання іноземної мови як комплексу застосування комп'ютерної та мультимедійних технологій. Окреслено методичні принципи та базові компоненти моделі навчання. Визначено функції комп'ютерної технології, мультимедійного забезпечення, завдання для викладача та можливості студента.

Ключові слова: дистанційне навчання, комп'ютерні технології, іноземна мова, мультимедійні технології, іншомовна компетенція 
Бебых В.В., Котелевская Р. А.

Методологические и дидактические основы формирования иноязычной коммуникативной компетентности в условиях дистанционного обучения

\section{Аннотация}

Целью статьи является обоснование педагогических условий и методических принципов формирования иноязычной коммуникативной компетентности будущего специалиста в условиях дистанционного обучения. Результатом исследования является создание педагогической модели формирования иноязычной коммуникативной компетентности на основе использования мультимедийного контента как интегрированного компонента комплекснометодического обеспечения и компьютерной технологии как формы организации процесса.

Методы анализа, синтеза, обобщения и моделирования легли в основу разработки модели. Структурный метод и системный анализ применялись для отображения связей между ее базовыми компонентами.

Обоснована система педагогических условий дистанционного обучения иностранному языку как комплекса применения компьютерной и мультимедийных технологий. Определены методические принципы и базовые компоненты модели обучения. Определены функции компьютерной технологии, мультимедийного обеспечения, задания для преподавателя и возможности студента.

Ключевые слова: дистанционное обучение, компьютерные технологии, иностранный язык, мультимедийные технологии, иноязычная компетенция 